\title{
Contrasting Patterns of Genetic Diversity and Population Structure of Armillaria mellea sensu stricto in the Eastern and Western United States
}

\author{
Kendra Baumgartner, Renaud Travadon, Johann Bruhn, and Sarah E. Bergemann
}

\begin{abstract}
First author: United States Department of Agriculture-Agricultural Research Service (USDA-ARS), Department of Plant Pathology, University of California, One Shields Avenue, Davis 95616; second author: Department of Plant Pathology, University of California, Davis; third author: Division of Plant Sciences, University of Missouri, 109 Waters Hall, Columbia 65211; and fourth author: Middle Tennessee State University, Biology Department, P.O. Box 60, Murfreesboro 37132.
\end{abstract} Accepted for publication 16 March 2010.

\begin{abstract}
Baumgartner, K., Travadon, R., Bruhn, J., and Bergemann, S. E. 2010. Contrasting patterns of genetic diversity and population structure of Armillaria mellea sensu stricto in the eastern and western United States. Phytopathology 100:708-718.

Armillaria mellea infects hundreds of plant species in natural and managed ecosystems throughout the Northern hemisphere. Previously reported nuclear genetic divergence between eastern and western U.S. isolates is consistent with the disjunct range of A. mellea in North America, which is restricted mainly to both coasts of the United States. We investigated patterns of population structure and genetic diversity of the eastern (northern and southern Appalachians, Ozarks, and western Great Lakes) and western (Berkeley, Los Angeles, St. Helena, and San

Jose, CA) regions of the United States. In total, 156 diploid isolates were genotyped using 12 microsatellite loci. Absence of genetic differentiation within either eastern subpopulations $\left(\theta_{S T}=-0.002, P=0.5\right)$ or western subpopulations $\left(\theta_{S T}=0.004, P=0.3\right)$ suggests that spore dispersal within each region is sufficient to prevent geographic differentiation. In contrast to the western United States, our finding of more than one genetic cluster of isolates within the eastern United States $(K=3)$, revealed by Bayesian assignment of multilocus genotypes in STRUCTURE and confirmed by genetic multivariate analyses, suggests that eastern subpopulations are derived from multiple founder sources. The existence of amplifiable and nonamplifiable loci and contrasting patterns of genetic diversity between the two regions demonstrate that there are two geographically isolated, divergent genetic pools of A. mellea in the United States.
\end{abstract}

Armillaria root disease attacks fruit and nut crops, timber trees, and ornamentals in temperate and tropical regions of the world (47). The causal pathogens are Armillaria spp. (Basidiomycota, Physalacriaceae), one of the most aggressive of which is Armillaria mellea (Vahl) P. Kumm., known primarily for its virulence against fruit and nut crops (e.g., Citrus, Juglans, Malus, Prunus, and Vitis spp.) throughout the Northern hemisphere $(11,38,40,68)$. Armillaria root disease affects vineyards and orchards established on previously forested land, where A. mellea infects a broad range of native species (70). After clearing infected native trees, mycelium surviving saprophytically in residual roots serves as inoculum for infection of planted hosts (72). The persistence of the mycelium in residual roots (13) and the lack of methods to either prevent $(17,37,59)$ or cure infections $(1,3)$ contribute to significantly reduced yields throughout the life of an infected plantation (9).

In nature, $A$. mellea populations consist of diploid individuals (84). The pathogen spreads vegetatively as its mycelium or rhizomorphs grow from infected roots into contact with roots of adjacent, susceptible hosts, thereby forming expanding disease centers within infected vineyards, orchards, and forests. A disease center is often occupied by a single, diploid individual of $A$. mellea $(12,13,65,75)$. Basidiospores, which germinate to form haploid mycelia (43), are thought to have little role in root infection, in part because only diploid mycelium is recovered from symptomatic plants and also due to numerous failed inocu-

Corresponding author: S. E. Bergemann; E-mail address: sbergema@mtsu.edu

doi:10.1094/PHYTO-100-7-0708

(C) 2010 The American Phytopathological Society lation attempts with basidiospores (73). Nonetheless, evidence of gene flow among populations of other Armillaria spp., A. ostoyae (69) and A. gallica (76), suggests that there is unrestricted spore dispersal across large geographic regions (maximum distances of 160 and 2,000 km, respectively).

It has been 30 years since A. mellea sensu stricto was recognized to be one of the many annulate North American Armillaria spp. $(7,39,85)$. The genus Armillaria in North America was previously considered to be a single species, A. mellea sensu lato, until it was recognized that there were multiple biological species (7), which have since been described as different species $(39,85)$. The North American biological species that was interfertile with European isolates of A. mellea retained the name of "A. mellea sensu stricto". Within North America, the geographic distribution of A. mellea sensu stricto is primarily restricted to both coasts of the United States, with limited reports from the central United States (e.g., Michigan [68] and Missouri [19]), and from outside the United States (e.g., southeastern Canada [28] and northeastern Mexico [4]). In the western United States, $A$. mellea is a virulent pathogen of fruit and nut crops (11). In the eastern United States, it is uncommon on these same crops (e.g., peach) (77) but, instead, is found more frequently on hardwood trees in forest ecosystems $(19,57)$. The disjunct geographic range of $A$. mellea coincides with nuclear genetic divergence observed in isolates originating from the eastern United States, the western United States, Europe, and Asia (22,23,55,58). Despite such support for intercontinental genetic divergence of A. mellea populations, there is little known about the origin and diversification of A. mellea.

For the purposes of this research, we focus on understanding the patterns of population structure and genetic diversity of $A$. 
mellea within the eastern and western regions of the United States. We use multilocus genotypes obtained from polymorphic microsatellite loci to (i) examine genetic differentiation between eastern and western U.S. populations of A. mellea, (ii) evaluate patterns of diversity among subpopulations within the eastern and western regions of the United States, and (iii) determine whether there is population structure within each region, regardless of the geographic origins of the isolates.

\section{MATERIALS AND METHODS}

Collection. Isolates were sampled from two regions: the eastern and western United States. The population of eastern U.S. isolates represented four subpopulations: northern Appalachians (N. Appalachians), southern Appalachians (S. Appalachians), the Ozark Mountains (Ozarks), and the western Great Lakes (W. Great Lakes) (Fig. 1A). Eastern isolates were obtained from existing collections at the United States Department of Agriculture (USDA) Forest Products Lab, the University of Missouri, and the University of Tennessee, and were gathered from natural ecosystems characterized primarily by hardwood tree species (Table 1). Identity was confirmed based on diagnostic patterns of restriction fragments resulting from $A l u I$ digestion of the nuclear ribosomal DNA intergenic spacer region I (IGS-I) (42). In total, 84 isolates were identified as A. mellea (AluI fragments of 490 and $180 \mathrm{bp}$; eastern U.S. restriction pattern) (42).

The population of western U.S. isolates represented four subpopulations, all of which were from California: St. Helena, Berkeley, San Jose, and Los Angeles (Fig. 1B). The St. Helena subpopulation was gathered from a mixed-hardwood forest, consisting primarily of naturally established hardwoods and the occasional softwood (Table 1). The other western subpopulations were gathered from suburban areas consisting of various orchard and forest trees remaining after residential development, and ornamentals in home gardens. In the laboratory, portions of decayed wood, mycelial fans, or basidiocarp stipes were transferred to $1 \%$ water agar (WA) containing benomyl 50WP $(4 \mu \mathrm{g} / \mathrm{ml})$ and streptomycin sulfate $(100 \mu \mathrm{g} / \mathrm{ml})$, incubated in darkness at $25^{\circ} \mathrm{C}$ for 7 days and further purified by hyphal tip subculture. In total, 72 isolates were identified as A. mellea (AluI fragments of 320 and $150 \mathrm{bp}$; western U.S. restriction pattern) (42).

Isolates were prepared for DNA extraction and subsequent microsatellite genotyping by incubation at $25^{\circ} \mathrm{C}$ for 7 to 28 days on $1 \%$ malt extract agar (MEA) overlain with cellophane. Mycelium was scraped from the cellophane with a sterile scalpel, then pulverized by beating with 6-mm glass beads for $20 \mathrm{~s}$ (FastPrep 120A; BioSpec, Bartlesville, OK). Mycelia were incubated at $65^{\circ} \mathrm{C}$ for 0.5 to $12 \mathrm{~h}$ in cetyltrimethylammonium bromide (CTAB) extraction buffer (100 mM Tris- $\mathrm{HCl}, \mathrm{pH} 8.0 ; 1.4 \mathrm{M}$ $\mathrm{NaCl} ; 20 \mathrm{mM}$ EDTA; and 2\% CTAB), after which $350 \mu \mathrm{l}$ of phenol-chloroform-isoamyl alcohol (25:24:1) was added to each tube, vortexed briefly, and centrifuged for $15 \mathrm{~min}$ at $14,000 \mathrm{rpm}$. The aqueous phase was mixed with $700 \mu \mathrm{l}$ of genomic salt solution and purified with $70 \% \mathrm{EtOH}$ after binding to glassmilk spin columns (MP Biomedicals, Santa Ana, CA), and DNA was eluted with $30 \mu \mathrm{l}$ of $0.1 \times$ Tris-EDTA.

Microsatellite genotyping. All 156 isolates were genotyped with 12 microsatellite markers (10). Loci were chosen for population genetic analyses based on positive amplification, polymorphism, and lack of linkage disequilibrium or severe heterozygote deficiencies, as previously described (10).

Population genetic analyses. All four western subpopulations consisted of one geographic location per subpopulation (Table 1). All four eastern subpopulations each consisted of more than one, relatively close, geographic locations per subpopulation (N. Appalachians, S. Appalachians Ozarks, and W. Great Lakes). Somatic incompatibility tests (79) were conducted to differentiate isolates into somatic incompatibility groups (SIGs) within each subpopulation, in order to reduce the likelihood of including more than one isolate representing the same vegetative individual, especially for isolates originating from adjacent trees. After categorization of isolates into SIGs within each subpopulation, we determined which SIGs had identical multilocus genotypes (MLGs) within or across subpopulations using GENCLONE version 2.0 (8). The same program was used to estimate the probability that an MLG found more than once was the result of a distinct sexual reproductive event $\left(P_{\text {gen }}(f)\right)(62)$, which is an estimate of $P_{\text {gen }}$ adapted for diploids and is based on the estimated fixation index $F_{\text {IS }}(92)$. Also, we estimated the probability of an MLG to be present a second time, assuming random mating $\left(P_{\text {sex }}\right.$ (f)) (62).

In each subpopulation, genotypic diversity $\left(G_{\mathrm{d}}\right)$ was estimated as the probability that two isolates randomly selected from the

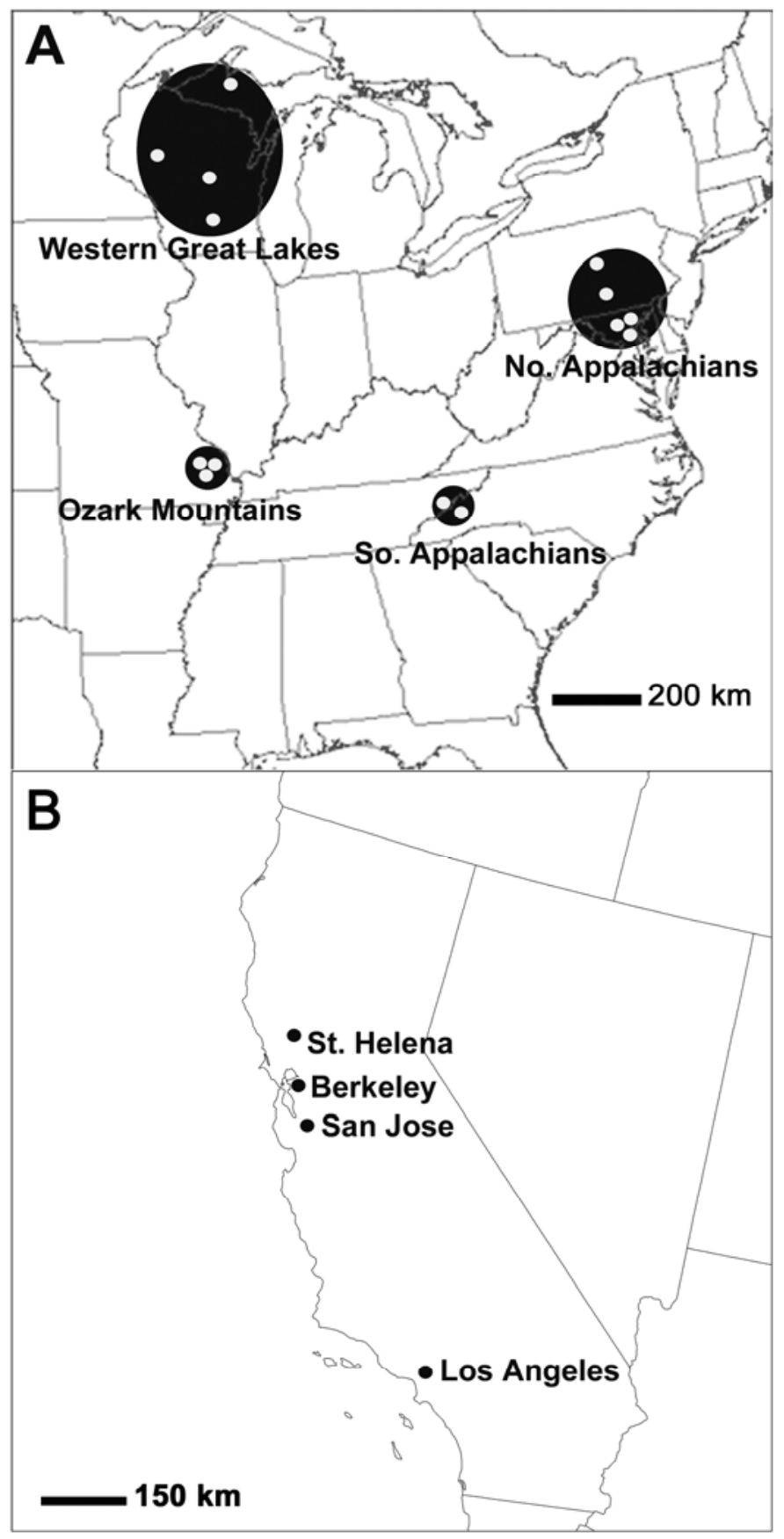

Fig. 1. Geographic locations of Armillaria mellea subpopulations in A, the eastern United States and B, the western United States. Circled points represent geographic locations grouped according to proximity. 
subpopulation represent different MLGs, using MULTILOCUS version 1.3 (2), with isolates containing missing data (i.e., null alleles) not contributing to the estimation of differences between pairs of isolates. To account for variable sample size, we calculated the expected number of MLGs in a subpopulation of $N=7$ $\left(G_{7}\right)$, which corresponded to the smallest subpopulation in the dataset (W. Great Lakes), according to the rarefaction equations of Hurlbert (48), using ANALYTIC RAREFACTION version 1.3 (46). To prevent overrepresentation of alleles due to the presence of clones (41), clone-corrected datasets were used for further analyses.

Genetic diversity within each subpopulation was assessed by estimating mean number of alleles per locus $(A)$, allelic richness corrected for sample size $(R)$, observed heterozygosity $\left(H_{\mathrm{O}}\right)$, and unbiased expected heterozygosity $\left(H_{\mathrm{E}}\right)$, using FSTAT version 2.9.3 (36). FSTAT accommodates variable sample size in calcu- lating allelic richness using an adaptation of the rarefaction index; it estimates the expected number of alleles in a subsample of $2 \mathrm{~N}$ loci after correction for the smallest sample size. To address the fact that there were different sampling schemes for the eastern and western United States (multiple geographic locations per subpopulation versus one geographic location per subpopulation), we estimated allelic richness and the richness of alleles observed in only one subpopulation (private allelic richness) to account for different hierarchical sampling and different numbers of loci, in addition to different sample sizes among subpopulations, using HP-Rare (51). In addition, Spearman correlation rank tests were conducted to measure the intensity of association between sampling area (i.e., the area including all geographic locations or sampling points per subpopulation) and genetic diversity (specifically, allelic richness and $G_{7}$ ). The CORR procedure of SAS (version 9.1; SAS Institute, Inc., Cary, NC) was applied to a data

TABLE 1. Armillaria mellea populations, consisting of diploid genotypes, from the eastern and western United States

\begin{tabular}{|c|c|c|c|c|}
\hline Population, location $^{\text {a }}$ & Coordinates & Area $\left(\mathrm{km}^{2}\right)^{\mathrm{b}}$ & Isolates $^{c}$ & Hosts \\
\hline \multicolumn{5}{|l|}{ Eastern United States } \\
\hline \multicolumn{5}{|l|}{ Northern Appalachians } \\
\hline Livonia, PA & $40^{\circ} 58^{\prime} \mathrm{N}, 77^{\circ} 17^{\prime} \mathrm{W}$ & NA & 1 & Quercus coccinea Münchh. \\
\hline Carlisle, PA & $40^{\circ} 12^{\prime} \mathrm{N}, 77^{\circ} 12^{\prime} \mathrm{W}$ & 0.4 & 18 & $\begin{array}{l}\text { Carya glabra (Mill.) Sweet, Fraxinus americana L., Q. coccinea Münchh., } \\
\text { Q. prinus L., Q. rubra L., Q. velutina Lam. }\end{array}$ \\
\hline Laurel, MD & $39^{\circ} 06^{\prime} \mathrm{N}, 76^{\circ} 51^{\prime} \mathrm{W}$ & NA & 1 & Quercus L. \\
\hline Beltsville, MD & $39^{\circ} 02^{\prime} \mathrm{N}, 76^{\circ} 54^{\prime} \mathrm{W}$ & NA & 1 & Quercus L. \\
\hline Bowie, MD & $38^{\circ} 57^{\prime} \mathrm{N}, 76^{\circ} 44^{\prime} \mathrm{W}$ & NA & 1 & Quercus L. \\
\hline Total & & 600 & 22 & \\
\hline \multicolumn{5}{|l|}{ Southern Appalachians } \\
\hline Oak Ridge, TN & $36^{\circ} 00^{\prime} \mathrm{N}, 84^{\circ} 14^{\prime} \mathrm{W}$ & 0.6 & 22 & Quercus L. \\
\hline Swain, NC & $35^{\circ} 39^{\prime} \mathrm{N}, 83^{\circ} 15^{\prime} \mathrm{W}$ & NA & 2 & Pinus L. \\
\hline Total & & 50 & 24 & \\
\hline \multicolumn{5}{|l|}{ Ozark Mountains } \\
\hline Carter County, $\mathrm{MO}^{\mathrm{d}}$ & $36^{\circ} 54^{\prime} \mathrm{N}, 90^{\circ} 56^{\prime} \mathrm{W}$ & 35 & 10 & $\begin{array}{l}\text { Cornus florida L., Q. alba L., Q. rubra L., Q. stellata Wangenh., } \\
\text { Q. velutina Lam. }\end{array}$ \\
\hline Reynolds County, $\mathrm{MO}^{\mathrm{d}}$ & $37^{\circ} 22^{\prime} \mathrm{N}, 90^{\circ} 58^{\prime} \mathrm{W}$ & 35 & 4 & Q. alba $\mathrm{L} ., Q$. coccinea Münchh. \\
\hline Shannon County, $\mathrm{MO}^{\mathrm{d}}$ & $37^{\circ} 12^{\prime} \mathrm{N}, 91^{\circ} 26^{\prime} \mathrm{W}$ & 35 & 17 & $\begin{array}{l}\text { C. florida L., } Q . \text { alba } \mathrm{L} ., Q \text {. coccinea } \text { Münchh., } Q . \text { marilandica Münchh., } \\
\text { Q. rubra L., Q. stellata Wangenh., } Q . \text { velutina Lam. }\end{array}$ \\
\hline Total & & 2,122 & 31 & \\
\hline \multicolumn{5}{|l|}{ Western Great Lakes } \\
\hline Baraga, MI & $46^{\circ} 46^{\prime} \mathrm{N}, 88^{\circ} 29^{\prime} \mathrm{W}$ & NA & 2 & Acer L. Quercus L. \\
\hline Elk Mound, WI & $44^{\circ} 52^{\prime} \mathrm{N}, 91^{\circ} 41^{\prime} \mathrm{W}$ & NA & 2 & A. saccharum Marsh. \\
\hline Hancock, WI & $44^{\circ} 07^{\prime} \mathrm{N}, 89^{\circ} 30^{\prime} \mathrm{W}$ & NA & 2 & Q. macrocarpa Michx. \\
\hline Wyocena, WI & $43^{\circ} 29^{\prime} \mathrm{N}, 89^{\circ} 18^{\prime} \mathrm{W}$ & NA & 1 & Quercus L. \\
\hline Total & & 61,608 & 7 & \\
\hline \multicolumn{5}{|l|}{ Western United States } \\
\hline \multicolumn{5}{|l|}{ Berkeley } \\
\hline Berkeley, CA & $37^{\circ} 52^{\prime} \mathrm{N}, 122^{\circ} 16^{\prime} \mathrm{W}$ & 0.2 & 10 & $\begin{array}{l}\text { Bergenia crassifolia (L.) Fritsch, Camellia japonica L., Cinnamomum camphora } \\
\text { (L.) J. Presl, Juniperus occidentalis Hook., Magnolia stellata (Siebold \& Zucc.) } \\
\text { Maxim., Pelargonium peltatum (L.) L'Hér. ex Aiton, Peumus boldus Molina, } \\
\text { Q. agrifolia Née, Rhododendron L. }\end{array}$ \\
\hline \multicolumn{5}{|r|}{ 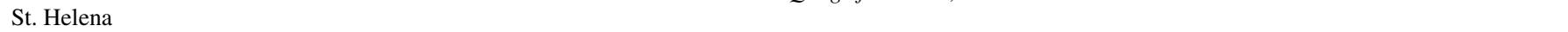 } \\
\hline St. Helena, CA & $38^{\circ} 30^{\prime} \mathrm{N}, 122^{\circ} 31^{\prime} \mathrm{W}$ & 0.4 & 33 & $\begin{array}{l}\text { Arbutus menziesii Pursh, Pseudotusuga menziesii (Mirb.) Franco, Q. agrifolia Née, } \\
\text { Q. kelloggii Newb., Sequoia sempervirens (D. Don) Endl. }\end{array}$ \\
\hline \multicolumn{5}{|r|}{ 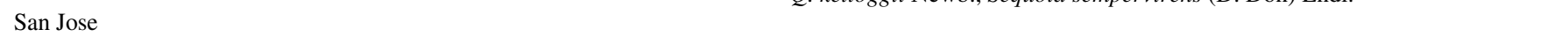 } \\
\hline San Jose, CA & $37^{\circ} 19^{\prime} \mathrm{N}, 121^{\circ} 52^{\prime} \mathrm{W}$ & 0.2 & 10 & $\begin{array}{l}\text { Cedrus deodara (Roxb.) G. Don, Cotoneaster integerrimus Medik., } \\
\text { Eucalyptus calophylla Lindl., Ilex sp. L., Juglans nigra L., } \\
\text { Liquidambar styraciflua L., Nerium oleander L., Pyrus betulifolium L. }\end{array}$ \\
\hline \multicolumn{5}{|r|}{ 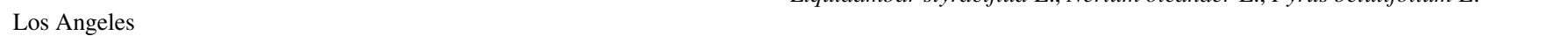 } \\
\hline Los Angeles, CA & $34^{\circ} 04^{\prime} \mathrm{N}, 118^{\circ} 25^{\prime} \mathrm{W}$ & 0.2 & 19 & $\begin{array}{l}\text { Citrus aurantium L., Cycas L., E. calophylla Lindl., J. occidentalis Hook., } \\
\text { P. peltatum }(\mathrm{L} .) \text { L'Hér. ex Aiton, Q. agrifolia Née, Q. suber L., } \\
\text { Salix } \times \text { sepulcralis Simonk., Schinus molle L., } \\
\text { Ulmus parvifolia Jacq., Washingtonia } \text { H. Wendl. }\end{array}$ \\
\hline
\end{tabular}

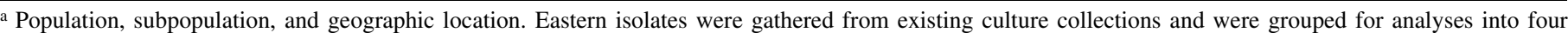
subpopulations, according to proximity of their geographic locations. Western isolates were collected from $0.2-\mathrm{km}^{2}$ areas at four geographic locations, representing four subpopulations.

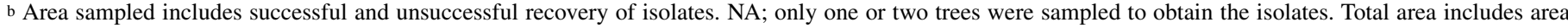
among all geographic locations per subpopulation.

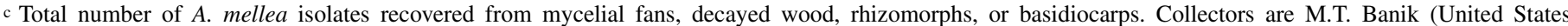
Department of Agriculture [USDA]-FS, Madison, WI), K. Baumgartner (USDA Agricultural Research Service, Davis, CA), H. H. Burdsall, Jr. (USDA-FS, Madison, WI), J. Bruhn (University of Missouri, Columbia), O. K. Miller, Jr. (Virginia Polytechnic Institute and State University, Blacksburg), K. Hughes and R. S. Petersen (University of Tennessee, Knoxville), J. M. Staley (USDA-FS, Fort Collins, CO), and P. M. Wargo (USDA-FS, Hamden, CT).

d Sampled as part of the Missouri Ozark Forest Ecosystem Project, MO $(19,80)$.
} 
set that combined allelic richness and $G_{7}$ as dependent variables, with sampling area as the independent variable. Inbreeding was estimated per subpopulation by computing the fixation index $F_{\text {IS }}$, and Fisher's exact tests were used to assess departure from Hardy-Weinberg equilibrium by estimating $P$ values with a Markov chain algorithm per locus per subpopulation, using GENEPOP version 4.0 (71). The same program was used to test for gametic linkage disequilibrium between each pair of loci within each subpopulation. The significance of association between genotypes per locus per subpopulation was tested with a log-likelihood ratio $G^{2}$ statistic, using the Monte Carlo Markov Chain (MCMC) algorithm implemented in GENEPOP (71). For each subpopulation, we computed the index of multilocus gametic disequilibrium $r_{\overline{\mathrm{d}}}$, using MULTILOCUS (2). The $r_{\overline{\mathrm{d}}}$ is based on the index of association $\left(I_{\mathrm{A}}\right)(18)$ but is independent of the number of loci; $r_{\overline{\mathrm{d}}}=0$ means there is no linkage disequilibrium. Significance of $r_{\overline{\mathrm{d}}}$ was evaluated by comparing the observed variance with the distribution of the variance expected under the null hypothesis of random mating, as determined from 1,000 randomized data sets in which alleles were permuted among genotypes.

Genetic structure of $A$. mellea populations was investigated by testing the null hypotheses of no genetic differentiation either between regions or between subpopulations within each region, using FSTAT to estimate $\theta_{\mathrm{ST}}(88)$, an unbiased estimator of the population differentiation index defined by Wright, $F_{\mathrm{ST}}(90)$. Significance levels were determined, after Bonferroni corrections, based on the adjusted $P$ value, with 5,000 permutations. Genetic differentiation between subpopulations across all loci was considered significantly different from 0 at both the 1 and 5\% nominal levels. Hierarchical distribution of genetic variation was estimated by analysis of molecular variance (AMOVA), using ARLEQUIN version 3.1 (32), with 5,000 permutations. AMOVA was used to determine the proportion of variation partitioned among subpopulations within a region and among isolates within a subpopulation.

A Bayesian method of assignment was implemented in STRUCTURE, version 2.2 (67). The principle of STRUCTURE is to use an MCMC algorithm to assign individuals to a genetic cluster based on their MLGs, regardless of their subpopulations. The method assumes that a genetic cluster is in Hardy-Weinberg equilibrium without significant linkage disequilibrium among loci. We performed two levels of assignment: (i) based on MLGs from all eight subpopulations of the eastern and western United States, to determine whether the highest posterior probability distributions assigned individuals to their respective population (i.e., eastern or western United States); and (ii) based on MLGs of subpopulations performed separately for each population, to determine whether our definition of "subpopulation" (based on the geographic origin of the isolates) was representative of population structure. In the former level of assignment, we anticipated that subpopulations from across the United States were likely to deviate from Hardy-Weinberg equilibrium, given that eastern and western populations likely represent two different gene pools with no gene flow between them $(22,23,55,58)$. However, our objective was to determine whether eastern and western U.S. isolates could be differentiated based on MLG variation.

Analysis of all eight subpopulations of the eastern and western United States was based on the five loci with positive amplicons for isolates in both U.S. regions (Am024, Am036, Am094, Am109, and Am125). Analysis of all four eastern subpopulations was based on the eight loci with positive amplicons for eastern isolates (Am024, Am036, Am094, Am109, Am111, Am124, Am125, and Am129). Analysis of all four western subpopulations was based on the nine loci with positive amplicons for western isolates (Am024, Am036, Am059, Am080, Am088, Am091, Am094, Am109, and Am125). The likelihood of the posterior probability distributions was computed for each genetic cluster
$(K=1-10)$ for these three data sets. Each model was simulated 10 times, with a run length of $15^{5}$ iterations after the specified burnin (50,000 iterations), under admixture (33). True $K$ was identified as the maximal value of the posterior probability of $\ln$ likelihood $[\mathrm{L}(K)]$ (31). However, given that $\mathrm{L}(K)$ typically plateaus or increases slightly after reaching true $K$, we estimated the number of genetic clusters as $\Delta K$, which is based on the rate of change of $\mathrm{L}(K)$ between successive $K$ values (31). In cases in which there was more than one genetic cluster, isolates were assigned to individual genetic clusters based on assignment scores $>80 \%$. Genetic differentiation among genetic clusters was assessed by estimating $\theta_{\mathrm{ST}}$. The contribution of each locus to genetic differentiation among genetic clusters was assessed by estimating Nei's estimator of genetic differentiation $\left(G_{\mathrm{ST}}\right)$, using FSTAT. Principal coordinates analysis (PCoA) was used to confirm genetic clusters inferred by STRUCTURE, based on a pairwise, individual-byindividual, genetic distance matrix (81), implemented in GENALEX, version 6 (64). PCoA is independent of assumptions used in STRUCTURE (e.g., Hardy-Weinberg and linkage equilibria) and groups isolates on a multidimensional scale.

\section{RESULTS}

Genetic diversity within subpopulations. For 5 of 12 loci (Am024, Am036, Am094, Am109, and Am125), positive amplicons were obtained for both eastern and western isolates ("amplifiable loci"). Remaining loci produced positive amplicons for only eastern isolates (Am111, Am124, and Am129; "nonamplifiable loci") or only western isolates (Am059, Am080, Am088, and Am091; nonamplifiable loci). Therefore, MLGs of all 84 eastern isolates were based on eight loci (Am024, Am036, Am094, Am109, Am111, Am124, Am125, and Am129) and those of all 72 western isolates were based on nine loci (Am024, Am036, Am059, Am080, Am088, Am091, Am094, Am109, and Am125). Of the five amplifiable loci, the size of the most common allele differed between eastern and western isolates for only two loci, Am024 and Am109, whereas sizes of the most common alleles were identical (albeit with different frequencies) for the three remaining loci (Am036, Am094, and Am125) (data not shown).

Expected heterozygosity $\left(H_{\mathrm{E}}\right)$ was 0.19 to 0.35 among eastern subpopulations and 0.40 to 0.43 among western subpopulations (Table 2). Significant departure from Hardy-Weinberg expectations, estimated by performing exact tests for each locus and subpopulation, indicated heterozygote deficiencies for seven of eight loci in the four eastern subpopulations (12 of 32 tests; $P<$ $0.05)$ and five of nine loci in the four western subpopulations $(8$ of 36 tests; $P<0.05)$. Heterozygote deficiencies were similarly evident in estimates of the inbreeding coefficient $\left(F_{\text {IS }}\right)$, which were significant for three of four eastern subpopulations (N. Appalachians, S. Appalachians, and Ozarks; $P<0.01$ and $P<$ 0.001 ) (Table 2). For the remaining eastern subpopulation (W. Great Lakes), negative $F_{\text {IS }}$ indicated heterozygote excess, although this was not significant $(P>0.05)$ and was likely due to low sample size $(N=7)$. Positive $F_{\text {IS }}$, indicating heterozygote deficiencies, were estimated for all western subpopulations, although values were significant only for the St. Helena subpopulation $(P<0.001) . F_{\text {IS }}$ values for each locus in the St. Helena subpopulation were positive but were significant for only two of nine loci: $\operatorname{Am088}\left(F_{\mathrm{IS}}=0.71, P<0.001\right)$ and $\operatorname{Am} 125\left(F_{\mathrm{IS}}=0.49\right.$, $P<0.01)$. The St. Helena subpopulation also had the highest number and richness of private alleles (Table 2).

Average allelic richness was typically higher in western than in eastern subpopulations ( $R=2.84$ to 3.43 versus 1.63 to 2.49 , respectively) (Table 2). In spite of variable sample sizes, $G_{\mathrm{d}}$ corrected for sample size, $G_{7}$, showed the same relative differences among subpopulations as that not corrected for sample size, $G_{\mathrm{d}}$. In all western subpopulations, no MLGs were shared among 
SIGs either within or across subpopulations; hence, $G_{\mathrm{d}}=1$ for each subpopulation. In contrast, $G_{\mathrm{d}}$ was lower in eastern subpopulations $\left(G_{\mathrm{d}}=0.94\right.$ to 0.98$)$ due to the presence of different SIGs that shared the same MLG within each eastern subpopulation (Table 2). Identical MLGs were also shared across some eastern subpopulations but none of the shared MLGs were shared between two locations per subpopulation. For five of seven identical MLGs that were shared among different SIGs across eastern subpopulations, the probability of a second encounter assuming random mating was high $\left(P_{\text {sex }}(f)>0.24\right)$, indicating that it is unlikely that these identical MLGs were the result of clonal spread. Similarly, for 21 of 22 identical MLGs that were shared among SIGs within eastern subpopulations, the probability of a second encounter assuming random mating was high $\left(P_{\text {sex }}(f)>\right.$ $0.39)$. Only two identical MLGs encountered in the same subpopulation (N. Appalachians) were likely the result of clonal spread $\left[P_{\text {sex }}(f)=1 \times 10^{-6}\right]$. There was a significant negative correlation between sampling area and allelic richness $(r=-0.76$, $P=0.030)$, and also between sampling area and $G_{7}(r=-0.92$, $P=0.014)$. Therefore, despite larger sampling areas (Table 1), eastern U.S. subpopulations had lower genetic diversity in terms of both allelic richness and $G_{7}$.

Linkage disequilibrium among alleles was not significant $(P>0.01)$ in any pairwise comparisons of loci within eastern or western subpopulations. Indices of multilocus linkage disequilibrium $\left(r_{\overline{\mathrm{d}}}\right)$ were not significant in seven of the eight sub- populations. Only the St. Helena subpopulation from the western United States presented a significant $r_{\overline{\mathrm{d}}}(P=0.001)$ (Table 2).

Genetic diversity among subpopulations. Within the eastern United States, none of the pairwise comparisons revealed significant differentiation among subpopulations $\left(\theta_{\mathrm{ST}}=-0.01\right.$ to $0.01 ; P=0.5$ ) (Table 3), which spanned a maximal distance of $1,200 \mathrm{~km}$ (Fig. 1A). Results were similar within the western United States; there was no significant differentiation among subpopulations $\left(\theta_{\mathrm{ST}}=-0.006\right.$ to $0.010 ; P=0.3$ ) (Table 3 ), which spanned a maximal distance of $700 \mathrm{~km}$ (Fig. 1B). Similarly, AMOVA showed that genetic differences among subpopulations did not contribute significantly to total genetic variation within eastern or western populations ( $P=0.8$ and 0.3 , respectively) (Table 4). AMOVA revealed that 99.4 and $98.8 \%$ of the variance within eastern and western populations, respectively, was due to genetic differences among isolates within subpopulations $(P<$ $0.001)$.

Bayesian assignment analyses. In assignment tests conducted with all eastern and western subpopulations, likelihood values associated with the posterior probability distributions implemented by STRUCTURE increased from $K=1$ to $K=5$ (data not shown). The number of genetic clusters $(K=2)$ was based on criteria described earlier (i.e., increase in standard deviation of the probability, assignment rates of isolates to each cluster, and computation of $\Delta K$ ). At the threshold of probability of assignment

TABLE 2. Genetic diversity of four eastern and four western U.S. subpopulations of Armillaria mellea, revealed using eight microsatellite loci (Am024, Am036, Am094, Am109, Am111, Am124, Am125, and Am129) and nine microsatellite loci (Am024, Am036, Am059, Am080, Am088, Am091, Am094, Am109, and Am125), respectively

\begin{tabular}{|c|c|c|c|c|c|c|c|c|c|c|c|}
\hline Population, subpopulation & $N^{\mathrm{a}}$ & $\mathrm{G}^{\mathrm{b}}$ & $G_{\mathrm{d}}^{\mathrm{c}}$ & $G_{7}^{\mathrm{d}}$ & $A^{\mathrm{e}}$ & $R^{\mathrm{f}}$ & $\mathrm{PA}^{\mathrm{g}}$ & $H_{\mathrm{O}}^{\mathrm{h}}$ & $H_{\mathrm{E}}^{\mathrm{i}}$ & $F_{\text {IS }}^{\mathrm{j}}$ & $r_{\mathrm{d}}^{\mathrm{k}}$ \\
\hline \multicolumn{12}{|l|}{ Eastern United States } \\
\hline Northern Appalachians & 22 & $15(4)$ & 0.94 & 6.2 & 2.75 & $2.19(1.76)$ & $3(0.29)$ & 0.20 & 0.30 & $0.34 * *$ & 0.070 \\
\hline Southern Appalachians & 24 & $21(5)$ & 0.98 & 6.8 & 3.13 & $2.36(1.89)$ & $2(0.36)$ & 0.15 & 0.34 & $0.55^{* * *}$ & 0.036 \\
\hline Western Great Lakes & 7 & $6(3)$ & 0.95 & 6 & 1.63 & $1.63(1.49)$ & $0(0.14)$ & 0.23 & 0.19 & -0.22 & -0.009 \\
\hline \multicolumn{12}{|l|}{ Western United States } \\
\hline Berkeley & 10 & $10(0)$ & 1.00 & 7 & 3.00 & $2.90(2.34)$ & $2(0.23)$ & 0.40 & 0.40 & 0.17 & -0.032 \\
\hline Los Angeles & 17 & $17(0)$ & 1.00 & 7 & 3.33 & $2.84(2.36)$ & $2(0.23)$ & 0.65 & 0.40 & 0.13 & -0.002 \\
\hline
\end{tabular}

a Number of somatic incompatibility groups (SIGs).

${ }^{\mathrm{b}}$ Number of multilocus genotypes (MLGs). Numbers of MLGs shared with other subpopulations are in parentheses.

${ }^{\mathrm{c}}$ Genotypic diversity.

${ }^{\mathrm{d}}$ Expected number of MLGs in a subpopulation of $N=7$ (size of the smallest subpopulation).

e Mean number of alleles.

f Allelic richness corrected for sample size. Allelic richness accounting for hierarchical sampling and number of loci in parentheses.

$\mathrm{g}$ Total number of private alleles across loci. Private allelic richness, accounting for hierarchical sampling and number of loci, averaged across loci in parentheses.

${ }^{\text {h }}$ Observed heterozygosity.

${ }^{\mathrm{i}}$ Unbiased expected heterozygosity.

j Fixation index; ** and *** indicate $P<0.01$ and 0.001 , respectively.

${ }^{\mathrm{k}}$ Index of multilocus linkage disequilibrium; $* *$ and $* * *$ indicate $P<0.01$ and 0.001 , respectively.

TABLE 3. Estimates $\theta_{\mathrm{ST}}$ of pairwise $F_{\mathrm{ST}}$ values (88), averaged across eight microsatellite loci (Am024, Am036, Am094, Am109, Am111, Am124, Am125, and Am129) for four eastern U.S. subpopulations and nine microsatellite loci (Am024, Am036, Am059, Am080, Am088, Am091, Am094, Am109, and Am125) for four western U.S. subpopulations of Armillaria mellea

\begin{tabular}{|c|c|c|c|c|}
\hline \multirow[b]{2}{*}{ Population, subpopulation } & \multicolumn{4}{|c|}{ Genetic differentiation $\left(\theta_{\mathrm{ST}}\right)$} \\
\hline & Northern Appalachians & Ozark Mountains & Southern Appalachians & Western Great Lakes \\
\hline \multicolumn{5}{|l|}{ Eastern United States } \\
\hline Northern Appalachians & & $\ldots$ & $\ldots$ & $\ldots$ \\
\hline Southern Appalachians & 0.013 & -0.004 & $\ldots$ & $\ldots$ \\
\hline Western Great Lakes & -0.013 & -0.012 & 0.001 & $\ldots$ \\
\hline Western United States & Berkeley & Los Angeles & San Jose & St. Helena \\
\hline San Jose & 0.006 & 0.010 & $\ldots$ & $\ldots$ \\
\hline St. Helena & 0.004 & 0.009 & -0.005 & $\ldots$ \\
\hline
\end{tabular}


(0.80), $90 \%$ of all isolates were assigned to either one of two clusters. In all, $92 \%$ of western isolates were assigned to one cluster, "Western United States", as were $2 \%$ of eastern isolates (a single isolate from the Ozarks) (Fig. 2). The Ozark isolate in the Western U.S. cluster was somewhat unique among eastern isolates in that it was homozygous for alleles that were most frequent among western isolates at two of five amplifiable loci (Am024 and Am109) and had a low frequency of unique alleles at the three remaining amplifiable loci (Am036, Am094, and Am125) (data not shown). Nonetheless, this Ozark isolate had positive polymerase chain reaction (PCR) amplicons for the three nonamplifiable loci that were specific to eastern isolates (Am111, Am124, and Am129). The second cluster, "Eastern United States", consisted entirely of eastern isolates ( $87 \%$ of all eastern isolates). The third cluster, "Both", consisted of isolates that were not assigned strongly to either cluster. Both consisted of $11 \%$ of eastern isolates and $8 \%$ of western isolates. Genetic differentiation among the three clusters was significant $\left(\theta_{\mathrm{ST}}=0.07\right.$ to $0.32 ; P<0.05)$.

The maximum ln likelihood of the posterior probability distribution implemented in STRUCTURE for the western subpopulations reached a maximum value when $K=1$ (data not shown). We performed no assignment, because a single genetic cluster contained all western isolates. In contrast, for the eastern subpopulations, posterior probability distributions increased from $K=1$ to $K=5$, and an increase in the standard deviation of the posterior probability obtained from 10 iterations at $K>3$, in addition to our calculation of $\Delta K$, further supported $K=3$.

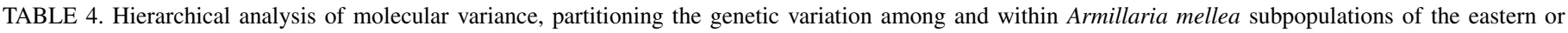
western United States

\begin{tabular}{|c|c|c|c|c|c|}
\hline Population, source of variation ${ }^{\mathrm{a}}$ & df & Sum of squares & Variance components & Percentage of variation & $P$ value \\
\hline \multicolumn{6}{|l|}{ Eastern United States } \\
\hline Among subpopulations & 3 & 3.73 & 0.01 & 0.58 & 0.76 \\
\hline Within subpopulations & 112 & 119.90 & 1.07 & 99.4 & $<0.001$ \\
\hline Total & 115 & 123.63 & 1.08 & 100 & $\ldots$ \\
\hline \multicolumn{6}{|l|}{ Western United States } \\
\hline Among subpopulations & 3 & 7.50 & 0.02 & 1.2 & 0.31 \\
\hline Within subpopulations & 114 & 212.28 & 1.86 & 98.8 & $<0.001$ \\
\hline Total & 117 & 219.77 & 1.88 & 100 & $\ldots$ \\
\hline
\end{tabular}

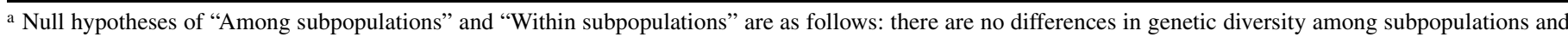
there are no differences in genetic diversity among isolates within the same subpopulation.

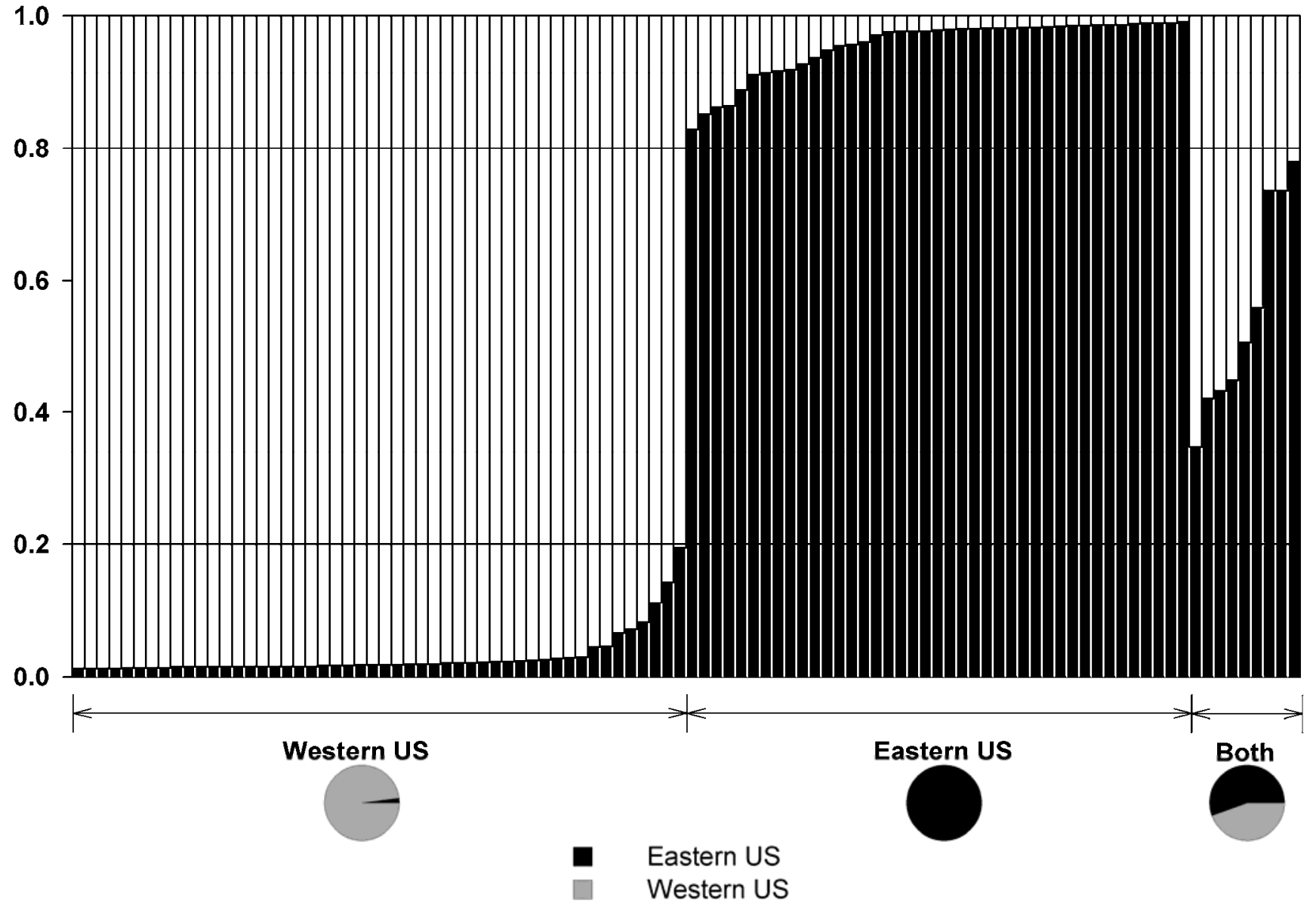

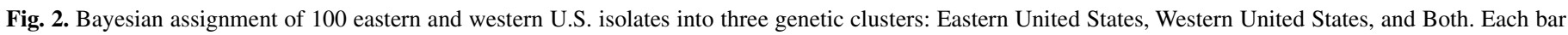

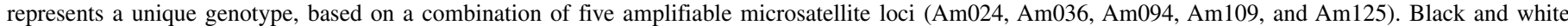

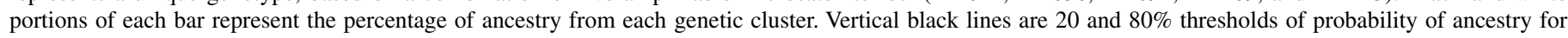
cluster assignment. Pie charts below each cluster reflect the relative proportions of isolates from each region of the United States. 
Furthermore, probabilities of assignment based on $K=4$ and $K=$ 5 were smaller than those for $K=3$ (data not shown). At the threshold for probability of assignment (0.80), 55\% of eastern isolates were assigned to one of three clusters and the remaining $45 \%$ were not assigned strongly to any one cluster ("Admixed") (Fig. 3). All four eastern subpopulations were represented in cluster 1 (33\% of N. Appalachian isolates, 33\% of Ozark isolates, $17 \%$ of S. Appalachian isolates, and $17 \%$ of W. Great Lakes isolates). The majority of isolates in cluster 2 were from the Ozarks $(66 \%)$ but isolates from both the N. and S. Appalachians were present ( 25 and $9 \%$, respectively). Cluster 3 was composed exclusively of isolates from the Ozarks and S. Appalachians (57 and $43 \%$, respectively). Genetic differentiation among the four clusters was significant $\left(\theta_{\mathrm{ST}}=0.08\right.$ to $\left.0.38 ; P<0.05\right)$. Of the eight loci used to genotype the eastern isolates, four loci (Am094, $\mathrm{Am} 024, \mathrm{Am} 036$, and Am125) had $G_{\mathrm{ST}}$ values $>0.10\left(G_{\mathrm{ST}}=0.47\right.$, $0.35,0.25$, and 0.11 , respectively), indicating that these four loci had relatively greater contributions to genetic differentiation of the four clusters in the eastern United States than did the remaining four loci $\left(G_{\mathrm{ST}}=0.031,0.044,0.002\right.$, and 0.023 for Am109, Am111, Am124, and Am129, respectively). PCoA showed that isolates grouped together into STRUCTURE clusters 1, 2, and 3 (Fig. 4). They were separated primarily by three principal components that explained $30.51,19.97$, and $17.10 \%$ of the variation (67.8\% total). Isolates in Admixed were scattered among clusters 1,2 , and 3 .

\section{DISCUSSION}

We identified two distinct gene pools in A. mellea from the eastern and western United States, consistent with phylogenetic divergence previously reported between eastern and western U.S. isolates $(22,23,55,58)$. Within each population (eastern or western United States), we found no evidence of significant genetic differentiation among subpopulations, although Bayesian assignment tests in STRUCTURE identified contrasting patterns of genetic structure and genetic diversity between populations: (i) western isolates formed a single deme and (ii) eastern isolates showed population structure, evidenced by three demes or genetic clusters. Together, our findings suggest that there is unrestricted gene flow within populations, although subpopulations from the western and eastern United States differ with respect to genetic variation within subpopulations.

Genetic divergence between eastern and western U.S. populations of $A$. mellea is supported by the existence of both amplifiable and nonamplifiable neutral genetic loci among isolates from these two regions. The presence of loci that are common to both eastern and western U.S. isolates may reflect either a common ancestral origin or gene flow through migration, establishment, and mating of immigrant isolates. Common ancestral origin of eastern and western A. mellea seems more likely than gene flow through migration as an explanation for the amplifiable loci, based on the vast distance $(\approx 4,000 \mathrm{~km})$ and the

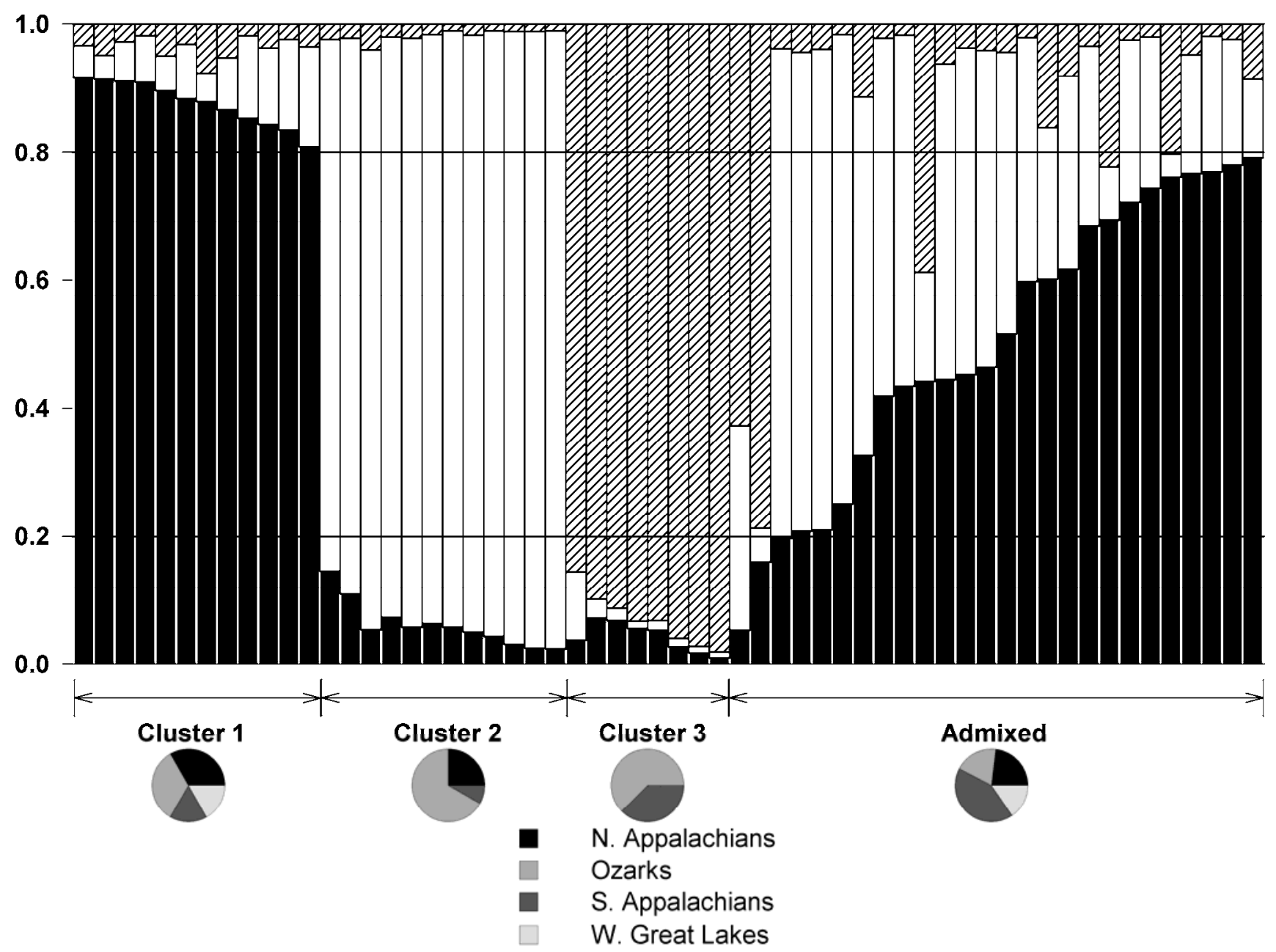

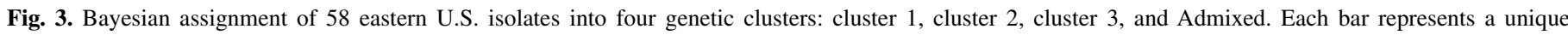
genotype based on a combination of eight microsatellite loci (Am024, Am036, Am094, Am109, Am111, Am124, Am125, and Am129). Black and white portions of each bar represent the percentage of ancestry from each genetic cluster. Vertical black lines are 20 and $80 \%$ thresholds of probability of ancestry for cluster assignment. Pie charts below each cluster reflect the relative proportions of isolates from each eastern U.S. subpopulation. 
presence of physical barriers to gene flow (e.g., Great Plains and Rocky Mountains) between the eastern and western United States, and the fact that the studied isolates came primarily from wild hosts and not from planted hosts. Indeed, other forest pathogens with disjunct geographic distributions in the United States have been shown to have genetically divergent populations (e.g., Heterobasidion annosum) (54). Nonamplifiable loci may represent sections of the genomes of eastern and western A. mellea with different evolutionary histories, likely the result of reproductive isolation or ecological speciation, as would be expected between populations under the divergent selective pressures exerted in distinct environments (56).

Genetic divergence between eastern and western U.S. populations of $A$. mellea is supported by Bayesian assignment tests that grouped isolates into two genetic clusters with respect to allelic frequencies and without a priori geographic information. Indeed, the majority of isolates were assigned to clusters composed primarily of either eastern or western isolates, thus confirming previous findings that eastern and western U.S. isolates of $A$. mellea, as examined in other studies $(22,23,55,58)$, represent genetically divergent populations. Our findings of one eastern isolate assigned to the Western cluster and some eastern and western isolates assigned to Both may be considered indications of admixture, due to migration and mating between populations. However, the eastern isolate assigned to the western cluster was unique in having common western alleles at two of five amplifiable loci and, thus, is unlikely to represent a mating event between eastern and western populations. Furthermore, the likelihood of this eastern isolate representing a mating event following transport of infected plant material is low, in part due to the fact that it was collected from a naturally established host in a forest, which is in contrast to the planted hosts in urban landscapes that characterize the only two known $A$. mellea introductions $(23,24)$. The presence of putatively admixed isolates in a third cluster (Both), representing isolates from both populations of the United States and in relatively equal proportions $(\approx 10 \%)$, suggests, first, that such isolates result from recombination between the two clusters and, second, that there is symmetric gene flow between clusters. Nonetheless, isolates assigned to Both had positive PCR amplicons for only the loci characteristic of their population of origin. Therefore, the reduced number of loci analyzed for this combined dataset (five) is likely to contribute to a low probability of assignment of such isolates to either Eastern or Western clusters and, thus, should not be considered as indicative of recombination between the two clusters.

Our findings of no significant $\theta_{\mathrm{ST}}$ among western subpopulations and significant admixture among eastern isolates in Bayesian assignment tests suggest that spore dispersal prevents genetic differentiation within each population. This is consistent with the broad range of $A$. mellea hosts distributed throughout each region (70). At the population scale of study (700 and 1,200 $\mathrm{km}$ in the western and eastern United States, respectively), we anticipate that spore dispersal is likely, because such spatial scales permit gene flow of other Armillaria spp. (76). Furthermore, other outcrossing Basidiomycetes that are, just as A. mellea, generalist, wood-decay fungi have little to no significant subdivision among geographically distant subpopulations (e.g., Fomitopsis pinicola [44], H. annosum [82], Phlebia centrifuga [34], and Trichaptum abietinum [52]). The spread of their spores, coupled with widespread availability of host substrate, apparently prevents genetic differentiation. This is in marked contrast to forest pathogens that are specialists or occur in fragmented habitats. For example, the wood-decay Basidiomycete Datronia caperata is found on a single host, Laguncularia racemosa (white mangrove). Its strong dependence on one host species, coupled with its disjunct distribution between coastal regions of Central America, contribute to significant population differentiation of $D$. caperata $(16,63)$. Fragmentation of forests inhabited by the primary host of F. rosea, old-growth Picea abies (Norway spruce), has likely contributed to significant levels of population structure of this wood-decay Basidiomycete in Europe (45).

Genetic divergence between eastern and western U.S. populations of A. mellea is supported by contrasting patterns of genetic diversity in each population. Genetic variation among eastern isolates based on Bayesian assignment of MLGs to more than one genetic cluster - not evident in $\theta_{\mathrm{ST}}$ estimates of differentiation among eastern subpopulations-suggests that there were multiple founder events in the eastern United States. Such a signature is not found in the western United States. Genetic diversity, in terms of allelic richness and $G_{7}$, was higher in the western than in the eastern United States, the latter of which was characterized by the presence of identical MLGs among SIGs both within and across subpopulations (although only two identical MLGs in one eastern subpopulation had high probabilities of representing the same individual). It is unlikely that differences in genetic diversity between the eastern and western United States are due to different sampling schemes (multiple versus one geographic location per subpopulation), because larger sampling areas in the eastern United States were not associated with higher genetic diversity corrected for sample size $\left(G_{7}\right)$ and for different sampling schemes (allelic richness). Lower heterozygote proportions than expected under Hardy-Weinberg equilibrium were identified in three of four eastern subpopulations versus one of four western subpopulations. Significant $F_{\text {IS }}$ values were previously identified for A. ostoyae in southwestern France (69) and A. gallica in the eastern United States (76). Heterozygote deficits in eastern subpopulations are likely due to the Wahlund effect (86), corresponding to inbreeding due to subdivision of one population into multiple subpopulations that do not freely exchange migrants. This hypothesis is supported by significant $\theta_{\mathrm{ST}}$ among the genetic clusters revealed by Bayesian assignment of eastern MLGs.

Our finding of three genetic clusters of isolates in the eastern United States suggests that eastern subpopulations are derived from founders from multiple sources, possibly due to independent

\section{$\square \quad$ Cluster 1 \\ $\triangle$ Cluster 2 \\ O Cluster 3 \\ $\times$ Admixed}

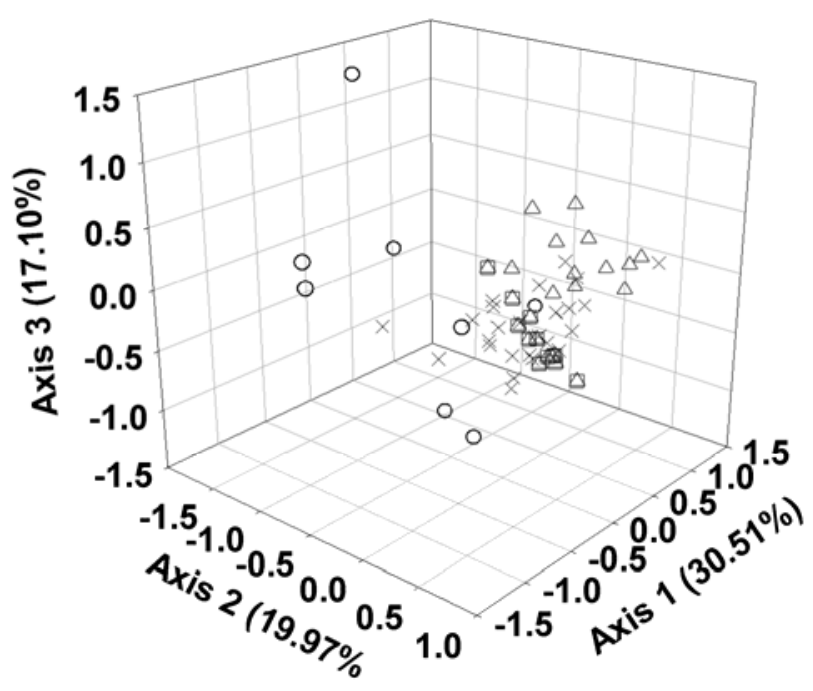

Fig. 4. Principal coordinates analysis of 58 eastern U.S. isolates. Each point represents an multilocus genotype based on a pairwise, individual-by-individual, genetic-distance matrix for eight microsatellite loci (Am024, Am036, Am094, Am109, Am111, Am124, Am125, and Am129). Percent variation explained by each axis is shown in parentheses. 
colonization events. Two clusters contained isolates from either three or four subpopulations and, thus, were not restricted to a specific geographic origin. In contrast, a third cluster was composed solely of isolates from the Ozark and S. Appalachian subpopulations, both of which represent the broader geographic region of the southeastern United States. Isolates in this third cluster may have inherited alleles from a divergent source population. Such alleles, although currently restricted to the southeastern United States, may eventually introgress into the whole eastern genetic pool of $A$. mellea, thereby erasing any signature of geographic structure. Indeed, the introgression into multiple subpopulations of alleles originating from a divergent source population is also a likely explanation for the assignment of isolates from three to four subpopulations each to the different genetic clusters. In contrast, the lack of genetic structure or, rather, a signature of such, within the western United States may reflect an older population, which is also supported by higher levels of genetic diversity, higher average allelic richness, and more private alleles. Older populations tend to have higher allelic richness, as demonstrated in populations of the Barley scald pathogen (Rhynchosporium secalis) (53), the Canker stain of plane tree pathogen (Ceratocystis fimbriata f. platani) (30), the Sudden oak death pathogen (Phytophthora ramorum) (49), and the Apple scab pathogen (Venturia inaequalis) (35), in contrast to newly established populations and their smaller effective populations sizes that make them more susceptible to loss of alleles through random genetic drift. It is also possible that higher levels of genetic diversity in the western United States reflect a higher effective population size than in the eastern United States (25). Alternatively, our microsatellite markers may be informative for inferring relatively recent gene flow in A. mellea populations in the United States but they may not accurately reflect historical barriers to gene flow and, thus, inferences regarding the relative ages of populations or their effective population sizes may be spurious. For example, differences in allelic richness between divergent populations can sometimes result from variable repeat lengths in microsatellite loci (78) or there may be directional mutational bias in cross-species amplifications (29). Thus, assessing the factors that contribute to differential allelic richness of eastern and western A. mellea populations may require analyses of loci that are not hypervariable but are, instead, more conserved and, thus, have a slower mutation process that is more informative for inferring ancient patterns.

In conducting somatic incompatibility tests prior to genotyping each isolate, we identified and eliminated biological clones (i.e., isolates representing more than one sample from the same mycelium) from our data sets. Nonetheless, tree-to-tree vegetative spread of Armillaria spp. is undoubtedly an important mechanism of disease spread $(69,74,89)$ and this mode of reproduction may affect our analyses, even in the absence of clones. For example, the combination of significant $F_{\text {IS }}$ and multilocus linkage disequilibrium in the St. Helena subpopulation may reflect a high rate of inbreeding through sibling matings (26) or somatic recombination through diploid-haploid matings (21). This subpopulation was the only one gathered from what is currently a natural ecosystem, and it is possible that, in such a continuously forested habitat, widespread host availability on a meter-by-meter scale allows for more frequent sibling matings or diploid-haploid matings than in managed ecosystems, where buildings and concrete replace $A$. mellea hosts. Interestingly, this subpopulation had the highest allelic richness and private allelic richness among all subpopulations examined but also exhibits signatures of inbreeding. The maintenance of high genetic diversity in this subpopulation, in spite of possible inbreeding, could be attributed to a higher effective population size relative to other populations from the western United States. Nonetheless, our findings of no population structure across much of the western United States and significant levels of admixture among genetically differentiated clusters of eastern U.S. isolates highlight the importance of sexual spores in long-distance dispersal and the maintenance of genetic diversity of A. mellea.

From a disease-control perspective, defining the species concept of a phytopathogenic fungus through examination of allelic variation from multiple nuclear loci is critical to determine the presence or absence of multiple species with differential pathogenicity and fungicide resistance (83). Within a described morphological species, the recognition of a greater number of distinct species through the analysis of molecular variation was previously documented for A. mellea sensu lato (6) and for other fungi (e.g., Aspergillus fumigatus [66], outcrossing Neurospora spp. [27], Schizophyllum commune [50], and Sclerotinia sclerotiorum [20]). This present study illustrates similar concepts, highlighting the existence of two divergent genetic pools of Armillaria mellea sensu stricto with contrasting genetic structure in geographically isolated regions of the United States. It is not known whether there are morphological differences or whether there are intersterility barriers between eastern and western U.S. A. mellea sensu stricto, because such comparisons have not been published to date. A preliminary comparison of morphology between fruiting bodies in our collection (all from the western United States) and published descriptions of fruiting bodies from both the eastern United States (57) and Europe (87) did reveal significant differences in several morphological characteristics (e.g., stipe, basidium, and basidiospore sizes) (data not shown). It is not known whether there are genetic barriers to mating between eastern and western U.S. populations, because published studies on matings with North American isolates include collections only from the eastern United States $(5,61)$. Nonetheless, our findings of genetic divergence, coupled with observations of differential virulence of $A$. mellea on the same fruit crops when grown in the eastern versus western United States $(11,57,77)$, highlight the importance of selecting strains based on geographic origin for rootstock breeding programs $(14,15)$ and in engineering rootstocks for resistance to Armillaria root disease $(60,91)$.

\section{ACKNOWLEDGMENTS}

We thank R. Peterson and K. Hughes (University of Tennessee, Knoxville) and J. Micales (USDA-FS Forest Products Lab, Madison, WI) for cultures; C. Dutech (Institut National de la Recherche Agronomique Bordeaux, France) for review of the manuscript; and P. Fujiyoshi and J. Groom (USDA Agricultural Research Service, Davis, CA) and T. Bowman (Middle Tennessee State University [MTSU], Murfreesboro, TN) for laboratory assistance. Funding was provided by Faculty Research and Creative Activity grant, MTSU (S. E. Bergemann) and USDA Cooperative State Research, Education, and Extension Service (K. Baumgartner).

\section{LITERATURE CITED}

1. Adaskaveg, J. E., Forster, H., Wade, L., Thompson, D. F., and Connell, J. H. 1999. Efficacy of sodium tetrathiocarbonate and propiconazole in managing Armillaria root rot of almond on peach rootstock. Plant Dis. $83: 240-246$.

2. Agapow, P. M., and Burt, A. 2001. Indices of multilocus linkage disequilibrium. Mol. Ecol. Notes 1:101-102.

3. Aguin, O., Mansilla, J. P., and Sainz, M. J. 2006. In vitro selection of an effective fungicide against Armillaria mellea and control of white root rot of grapevine in the field. Pest Manage. Sci. 62:223-228.

4. Alvarado-Rosales, D., and Blanchette, R. A. 1994. Armillaria species from forests of central Mexico. (Abstr.) Phytopathology 84:1106.

5. Anderson, J. B., Korhonen, K., and Ullrich, R. C. 1980. Relationships between European and North American biological species of Armillaria mellea. Exp. Mycol. 4:87-95.

6. Anderson, J. B., and Stasovsky, E. 1992. Molecular phylogeny of Northern hemisphere species of Armillaria. Mycologia 84:505-516.

7. Anderson, J. B., and Ullrich, R. C. 1979. Biological species of Armillaria mellea in North America. Mycologia 71:402-414.

8. Arnaud-Haond, S., and Belkhir, K. 2007. GENCLONE: a computer program to analyse genotypic data, test for clonality and describe spatial 
clonal organization. Mol. Ecol. Notes 7:15-17.

9. Baumgartner, K. 2004. Root collar excavation for postinfection control of Armillaria root disease of grapevine. Plant Dis. 88:1235-1240.

10. Baumgartner, K., Grubisha, L., Fujiyoshi, P., Garbelotto, M., and Bergemann, S. E. 2009. Microsatellite markers for the diploid Basidiomycete fungus, Armillaria mellea. Mol. Ecol. Res. 9:943-946.

11. Baumgartner, K., and Rizzo, D. M. 2001. Distribution of Armillaria species in California. Mycologia 93:821-830.

12. Baumgartner, K., and Rizzo, D. M. 2001. Ecology of Armillaria species in mixed-hardwood forests of California. Plant Dis. 85:947-951.

13. Baumgartner, K., and Rizzo, D. M. 2002. Spread of Armillaria Root Disease in a California vineyard. Am. J. Enol. Vitic. 53:197-203.

14. Beckman, T. G., Okie, W. R., Nyczepir, A. P., Pusey, P. L., and Reilly, C. C. 1998. Relative susceptibility of peach and plum germplasm to Armillaria root rot. HortScience 33:1062-1065.

15. Beckman, T. G., and Pusey, P. L. 2001. Field testing peach rootstocks for resistance to Armillaria root rot. HortScience 36:101-103.

16. Bergemann, S. E., Smith, M. A., Parrent, J. L., Gilbert, G. S., and Garbelotto, M. 2009. Genetic population structure and distribution of a fungal polypore, Datronia caperata (Polyporaceae), in mangrove forests of Central America. J. Biogeogr. 36:266-279.

17. Bliss, D. E. 1951. The destruction of Armillaria mellea in citrus soils. Phytopathology 41:665-683.

18. Brown, A. H. D., Feldman, M. W., and Nevo, E. 1980. Multilocus structure of natural populations of Hordeum spontaneum. Genetics 96:523536.

19. Bruhn, J. N., Wetteroff, J. J., Mihail, J. D., Kabrick, J. M., and Pickens, J. B. 2000. Distribution of Armillaria species in upland Ozark Mountain forests with respect to site, overstory species composition and oak decline. For. Pathol. 30:43-60.

20. Carbone, I., and Kohn, L. M. 2001. A microbial population-species interface: nested cladistic and coalescent inference with multilocus data. Mol. Ecol. 10:947-964.

21. Carvalho, D. B., Smith, M. L., and Anderson, J. B. 1995. Genetic exchange between diploid and haploid mycelia of Armillaria gallica. Mycol. Res. 6:641-647.

22. Coetzee, M. P. A., Wingfield, B. D., Harrington, T. C., Dalevi, D., Coutinho, T. A., and Wingfield, M. J. 2000. Geographical diversity of Armillaria mellea s. s. based on phylogenetic analysis. Mycologia 92:105-113.

23. Coetzee, M. P. A., Wingfield, B. D., Harrington, T. C., Steimel, J., Coutinho, T. A., and Wingfield, M. J. 2001. The root rot fungus Armillaria mellea introduced into South Africa by early Dutch settlers. Mol. Ecol. 10:387-396.

24. Coetzee, M. P. A., Wingfield, B. D., Roux, J., Crous, P. W., Denman, S., and Wingfield, M. J. 2003. Discovery of two northern hemisphere Armillaria species on Proteaceae in South Africa. Plant Pathol. 52:604612.

25. Criscione, C. D., Poulin, R., and Blouin, M. S. 2005. Molecular ecology of parasites: elucidating ecological and microevolutionary processes. Mol. Ecol. 14:2247-2257.

26. de Meeus, T., and Balloux, F. 2004. Clonal reproduction and linkage disequilibrium in diploids: a simulation study. Infect. Gen. Evol. 4:345351.

27. Dettman, J. R., Jacobson, D. J., and Taylor, J. W. 2003. A multilocus genealogical approach to phylogenetic species recognition in the model eukaryote Neurospora. Evolution 57:2703-2720.

28. Dumas, M. T. 1988. Biological species of Armillaria in the mixed wood forest of northern Ontario. Can. J. For. Res. 18:872-874.

29. Ellegren, H. 2004. Microsatellites: simple sequences with complex evolution. Nat. Rev. 5:435-445.

30. Engelbrecht, C. J. B., Harrington, T. C., Steimel, J., and Capretti, P. 2004. Genetic variation in eastern North American and putatively introduced populations of Ceratocystis fimbriata f. platani. Mol. Ecol. 13:2995-3005.

31. Evanno, G., Regnaut, S., and Goudet, J. 2005. Detecting the number of clusters of individuals using the software STRUCTURE: A simulation study. Mol. Ecol. 14:2611-2620.

32. Excoffier, L., Laval, G., and Schneider, S. 2005. Arlequin (version 3.0): an integrated software package for population genetics data analysis. Evol. Bioinf. 1:47-50.

33. Falush, D., Stephens, M., and Pritchard, J. K. 2003. Inference of population structure using multilocus genotype data: linked loci and correlated allele frequencies. Genetics 164:1567-1587.

34. Franzen, I., Vasaitis, R., Penttila, R., and Stenlid, J. 2007. Population genetics of the wood-decay fungus Phlebia centrifuga P. Karst. in fragmented and continuous habitats. Mol. Ecol. 16:3326-3333.

35. Gladieux, P., Zhang, X.-G., Afoufa-Bastien, D., Sanhueza, R.-M. V., Sbaghi, M., and Le Cam, B. 2008. On the origin and spread of the scab disease of apple: Out of central Asia. PLoS One 3:e1455.

36. Goudet, J. 1995. FSTAT (Version 1.2): A computer program to calculate F statistics. J. Hered. 86:485-486.

37. Gubler, W. D. 1992. Armillaria root rot. Pages $92-93$ in: Grape Pest Management, 2nd ed. D. L. Flaherty, L. P. Christensen, W. T. Lanini, J. J. Marois, P. A. Phillips, and L. T. Wilson, eds. University of California, Division of Agriculture and Natural Resources, Publ. No. 3343, Oakland.

38. Guillaumin, J. J. 1977. Apricot root rot, Armillariella mellea (Vahl) Karst. EPPO Bull. 7:125-135.

39. Guillaumin, J. J., Anderson, J. B., and Korhonen, K. 1991. Life cycle, interfertility, and biological species. Pages 10-47 in: Armillaria Root Disease. C. G. Shaw, III and G. A. Kile, eds. U. S. Dep. Agric. For. Serv. Agric. Handb. No. 691, Washington, DC.

40. Guillaumin, J. J., Mohammed, C., and Berthelay, S. 1989. Armillaria species in the Northern temperate Hemisphere. In: Proc. Seventh Int. Conf. Root Butt Rots, Victoria, British Columbia, Canada.

41. Halkett, F., Simon, J. C., and Balloux, F. 2005. Tackling the population genetics of clonal and partially clonal organisms. Trends Ecol. Evol. 20:194-201.

42. Harrington, T. C., and Wingfield, B. D. 1995. A PCR-based identification method for species of Armillaria. Mycologia 87:280-288.

43. Hintikka, V. 1973. A note on the polarity of Armillariella mellea. Karstenia 13:32-39.

44. Hogberg, N., Holdenrieder, O., and Stenlid, J. 1999. Population structure of the wood decay fungus Fomitopsis pinicola. Heredity 83:354-360.

45. Hogberg, N., and Stenlid, J. 1999. Population genetics of Fomitopsis rosea - a wood-decay fungus of the old-growth European taiga. Mol. Ecol. 8:703-710.

46. Holland, S. M. 2003. ANALYTIC RAREFACTION, version 1.3 www.uga.edu/ strata/software/Software.html

47. Hood, I. A., Redfern, D. B., and Kile, G. A. 1991. Armillaria in Planted Hosts. Pages 122-149 in: Armillaria Root Disease. C. G. Shaw, III and G. A. Kile, eds. U. S. Dep. Agric. For. Serv. Agric. Handb. No. 691, Washington, D.C.

48. Hurlbert, S. H. 1971. The nonconcept of species diversity: A critique and alternative parameters. Ecology 52:577-586.

49. Ivors, K., Garbelotto, M., Vries, I. D. E., Ruyter-Spira, C., Hekkert, B. T., Rosenzweig, N., and Bonants, P. 2006. Microsatellite markers identify three lineages of Phytophthora ramorum in U.S. nurseries, yet single lineages in U.S. forest and European nursery populations. Mol. Ecol. 15:1493-1505.

50. James, T. Y., Porter, D., Hamrick, J. L., and Vilgalys, R. 1999. Evidence for limited intercontinental gene flow in the cosmopolitan mushroom, Schizophyllum commune. Evolution 53:1665-1677.

51. Kalinowski, S. T. 2004. Counting alleles with rarefaction: private alleles and hierarchical sampling designs. Conserv. Gen. 5:539-543.

52. Kauserud, H., and Schumacher, T. 2003. Regional and local population structure of the pioneer wood-decay fungus Trichaptum abietinum. Mycologia 95:416-425.

53. Linde, C. C., Zala, M., and McDonald, B. A. 2009. Molecular evidence for recent founder populations and human-mediated migration in the barley scald pathogen Rhynchosporium secalis. Mol. Phylogenet. Evol. $51: 454-464$

54. Linzer, R. E., Otrosina, W. J., Gonthier, P., Bruhn, J., Laflamme, G., Bussieres, G., and Garbelotto, M. 2008. Inferences on the phylogeography of the fungal pathogen Heterobasidion annosum, including evidence of interspecific horizontal genetic transfer and of humanmediated, long-range dispersal. Mol. Phylogenet. Evol. 46:844-862.

55. Maphosa, L., Wingfield, B., Coetzee, M., Mwenje, E., and Wingfield, M. J. 2006. Phylogenetic relationships among Armillaria species inferred from partial elongation factor 1-alpha DNA sequence data. Australas. Plant Pathol. 35:513-520.

56. McKinnon, J. S., Mori, S., Blackman, B. K., David, L., Kingsley, D. M., Jamieson, L., Chou, J., and Schluter, D. 2004. Evidence for ecology's role in speciation. Nature 429:294-298.

57. Motta, J. J., and Korhonen, K. 1986. A note on Armillaria mellea and Armillaria bulbosa from the middle Atlantic states. Mycologia 78:471474.

58. Mueller, G. M., Wu, Q., Huang, Y., Guo, S., Aldana-Gomez, R., and Vilgalys, R. 2001. Assessing biogeographic relationships between North American and Chinese macrofungi. J. Biogeogr. 28:271-281.

59. Munnecke, D. E., Kolbezen, M. J., Wilbur, W. D., and Ohr, H. D. 1981. Interactions involved in controlling Armillaria mellea. Plant Dis. 65:384389.

60. Nagel, A. K., Schnabel, G., Petri, C., and Scorza, R. 2008. Generation and characterization of transgenic plum lines expressing the Gastrodia antifungal protein. HortScience 43:1514-1521.

61. Ota, Y., Matsushita, N., Terashita, T., Fukuda, K., and Suzuki, K. 1998. Biological species of Armillaria in Japan. Plant Dis. 82:537-543.

62. Parks, J. C., and Werth, C. R. 1993. A study of spatial features of clones in a population of bracken fern, Pteridium aquilinum (Dennstaedtiaceae). Am. J. Bot. 80:537-544 
63. Parrent, J. L., Garbelotto, M., and Gilbert, G. S. 2004. Population genetic structure of the polypore Datronia caperata in fragmented mangrove forests. Mycol. Res. 108:403-410.

64. Peakall, R., and Smouse, P. E. 2006. GENALEX 6: genetic analysis in Excel. Population genetic software for teaching and research. Mol. Ecol. Notes 6:288-295.

65. Pertot, I., Gobbin, D., De Luca, F., and Prodorutti, D. 2008. Methods of assessing the incidence of Armillaria root rot across viticultural areas and the pathogen's genetic diversity and spatial-temporal pattern in northern Italy. Crop Prot. 27:1061-1070.

66. Pringle, A., Baker, D. M., Platt, J. L., Wares, J. P., Latge, J. P., and Taylor, J. W. 2005. Cryptic speciation in the cosmopolitan and clonal human pathogenic fungus Aspergillus fumigatus. Evolution 59:1886-1899.

67. Pritchard, J. K., Stephens, M., and Donnelly, P. 2000. Inference of population structure using multilocus genotype data. Genetics 155:945959.

68. Proffer, T. J., Jones, A. L., and Ehret, G. R. 1987. Biological species of Armillaria isolated from sour cherry orchards in Michigan. Phytopathology 77:941-943.

69. Prospero, S., Lung-Escarmant, B., and Dutech, C. 2008. Genetic structure of an expanding Armillaria root rot fungus (Armillaria ostoyae) population in a managed pine forest in southwestern France. Mol. Ecol. 17:3366-3378.

70. Raabe, R. D. 1962. Host list of the root rot fungus Armillaria mellea. Hilgardia 33:25-88.

71. Raymond, M., and Rousset, F. 1995. GENEPOP (version 1.2): Population Genetics Software for Exact Tests and Ecumenicism. J. Hered. 86:248249.

72. Redfern, D. B., and Filip, G. M. 1991. Inoculum and infection. Pages 4861 in: Armillaria Root Disease. C. G. Shaw, III and G. A. Kile, eds. U. S. Dep. Agric. For. Serv. Agric. Handb. No. 691, Washington, D. C.

73. Rishbeth, J. 1970. The role of basidiospores in stump infection by Armillaria mellea. Pages 141-146 in: Root Diseases and Soil-borne Pathogens. T. A. Tousson, R. V. Bega, and P. E. Nelson, eds. University of California Press, Berkeley.

74. Rizzo, D. M., Blanchette, R. A., and May, G. 1995. Distribution of Armillaria ostoyae genets in a Pinus resinosa-Pinus banksiana forest. Can. J. Bot. 73:776-787.

75. Rizzo, D. M., Whiting, E. C., and Elkins, R. B. 1998. Spatial distribution of Armillaria mellea in pear orchards. Plant Dis. 82:1226-1231.

76. Saville, B. J., Yoell, H., and Anderson, J. B. 1996. Genetic exchange and recombination in populations of the root-infecting fungus Armillaria gallica. Mol. Ecol. 5:485-497.

77. Schnabel, G., Ash, J. S., and Bryson, P. K. 2005. Identification and characterization of Armillaria tabescens from the southeastern United States. Mycol. Res. 109:1208-1222.

78. Selkoe, K. A., and Toonen, R. J. 2006. Microsatellites for ecologists: a practical guide to using and evaluating microsatellite markers. Ecol. Lett. 9:615-629.

79. Shaw, C. G., III, and Roth, L. F. 1976. Persistence and distribution of Armillaria mellea in a ponderosa pine forest. Phytopathology 66:12101213.

80. Shifley, S. R., and Brookshire, B. L. 2000. Missouri Ozark Forest Ecosystem Project: Site history, soils, landforms, woody and herbaceous vegetation, down wood, and the inventory methods for the landscape experiment. Gen. Tech. Rep. NC-208. U. S. Dep. Agric. For. Serv. North Cent. For. Exp. Stn. St. Paul, MN.

81. Smouse, P. E., and Peakall, R. 1999. Spatial autocorrelation analysis of individual multiallele and multilocus genetic structure. Heredity 82:561573.

82. Stenlid, J., Karlsson, J. O., and Hogberg, N. 1994. Intraspecific genetic variation in Heterobasidion annosum revealed by amplification of minisatellite DNA. Mycol. Res. 98:57-63.

83. Taylor, J. W., Jacobson, D. J., and Fisher, M. C. 1999. The evolution of asexual fungi: reproduction, speciation and classification. Annu. Rev. Phytopathol. 37:197-246.

84. Ullrich, R. C., and Anderson, J. B. 1978. Sex and diploidy in Armillaria mellea. Exp. Mycol. 2:119-129.

85. Volk, T. J., Burdsall, H. H., Jr., and Banik, M. T. 1996. Armillaria nabsnona, a new species from western North America. Mycologia 88:484-491.

86. Wahlund, S. 1928. Composition of populations and correlation appearances viewed in relation to the studies of inheritance. Hereditas 11:65-106.

87. Watling, R., Kile, G. A., and Gregory, N. M. 1982. The genus Armillaria-nomenclature, typification, the identity of Armillaria mellea and species differentiation. Trans. Br. Mycol. Soc. 78:271-285.

88. Weir, B. S., and Cockerham, C. C. 1984. Estimating F-statistics for the analysis of population structure. Evolution 38:1358-1370.

89. Worrall, J. J. 1994. Population structure of Armillaria species in several forest types. Mycologia 86:401-407.

90. Wright, S. 1943. Isolation by distance. Genetics 28:114-138.

91. Xu, Q., Liu, Y., Wang, X., Gu, H., and Chen, Z. 1998. Purification and characterization of a novel anti-fungal protein from Gastrodia elata. Plant Physiol. Biochem. 36:899-905.

92. Young, A. G., Hill, J. H., Murray, B. G., and Peakall, R. 2002. Breeding system, genetic diversity and clonal structure in the sub-alpine forb Rutidosis leiolepis F. Muell. (Asteraceae). Biol. Conserv. 106:71-78. 